\title{
"It is All He Can Do to Cope with the Roads in His Own District": Labor, Community, and Development in Northern Ghana, 1919-1936*
}

\author{
Alice Wiemers \\ Davidson College
}

\begin{abstract}
In the 1920s and 1930s, colonial officials in Ghana's Northern Territories formulated the first development plans for this hinterland region. Administrators recast local roads and bridges as instruments of agricultural production and began to pursue small-scale resettlement efforts. In the absence of colonial funding, officials layered the requirements of development onto existing forced labor policies that took northerners to the cocoa- and gold-producing South. Using records from neighboring districts in the Northern Province, this article asks how demands for labor helped define the practice, experience, and limits of colonial authority. Intraregional mobility became a particular concern of officials as northerners began to "vote with their feet" to avoid forced labor. This article examines knotty cases in which questions of migration drew officials into local struggles to attract followers and manage the burdens of an extractive state. Northerners forced colonial officials to treat labor not just as something that could be extracted from bodies, but also as a political act involving subjects, chiefs, and officials. This article concludes in the early 1930s, when signers of the ILO's Forced Labour Convention formalized exceptions for labor that was demanded in the "direct interest of the community" or constituted "minor communal services." Far from eliminating state claims to labor, these initiatives increasingly enshrined them in emerging practices of development.
\end{abstract}

"It seems to me to involve grave issues," wrote District Commissioner Alan Wolsey Cardinall to the acting commissioner of the Northeastern Province of colonial Ghana's Northern Territories Protectorate on June 14, 1919. Referring to the question of policing northern Ghanaians' migration across recently established district boundaries, he questioned "how ... one is to draw the line and to distinguish when a man is a fugitive from work or when he is an emigrant to better his condition." ${ }^{1}$ In his letter, Cardinall invoked the principle of "freedom of choice" and the risk of colonial chieftaincy becoming "tyrannical." Four months later, in a prelude to more than a decade of debate on the subject, the commissioner of the Northwestern Province gave a less ambivalent interpretation: "[M]alcontents," he wrote, "will try to skip to the side where there is little or no work." 2

At the heart of this debate about migration was the question of how colonial officials would reconcile colonial labor demands with plans for agricultural and infrastructural development. By 1919, the Gold Coast administration had already begun to envision the region's labor as a resource for development 
plans in the export-producing South. Northern laborers were sent south to construct large-scale road, railway, and port infrastructure. ${ }^{3}$ Within the North, officials embarked on a much more modest set of "improvements," demanding forced labor to build both "administrative" and "economic" roads and to construct rest houses for visiting officials. Then, with the formalization of Governor Francis Gordon Guggisberg's ten-year development plan in the 1920s, recruitment of long-distance labor continued alongside the first efforts to cast northern infrastructure and agriculture as elements of development. ${ }^{4}$ These plans also relied on forced labor recruited by chiefs and administrators. By the late 1920s and 1930s, when the British government worked to shape and then comply with international forced labor bans, officials used a new rhetoric of "community interest" to legitimize and institutionalize local demands on northern labor.

Using records from several neighboring districts in colonial northern Ghana, this article builds on Carola Lentz's insight that the infrastructure of colonial administration not only constituted "the material framework of the new territorial order" but "functioned as an instrument in defining and asserting it." ${ }^{5}$ It asks how demands for labor to build this infrastructure helped define the practice, experience, and limits of colonial authority. Colonial officials did not have the power to fully define the terms on which labor demands were contested. ${ }^{6}$ Colonial developmentalism became embroiled in the local politics of labor as residents devised strategies to cope with the unpredictable and erratic application of colonial force. These strategies, in turn, drew officials into local struggles to attract followers and manage the burdens of an extractive state.

Part I uses monthly diaries of district commissioners (DCs) to show how northerners' strategies of resistance, combined with the colonial reliance on chiefs for labor recruitment, forced officials to confront the limits of their control over labor. ${ }^{7}$ Scholars have chronicled the widespread use of fines, imprisonment, and other forms of coercion as well as the prevalence of desertion and avoidance in response to recruitment for colonial road building in southern Ghana. ${ }^{8}$ By focusing on local recruitment within the North, this article is able to show how labor demands and strategies of resistance conditioned the first plans for northern agricultural development and efforts to "modernize" rule through automobile transit. These plans neatly sidestepped growing British and international critiques of forced labor, which continued to make exceptions for public works and local projects. ${ }^{9}$ Meanwhile, administrators grafted new demands onto existing structures of force and resistance that continued to draw officials into the local politics of forced labor.

Colonial officials who attempted to impose and legitimize demands for labor found themselves enmeshed in larger processes whereby chiefs and communities struggled to attract residents and secure their labor and loyalty. The clearest illustration of this dynamic came when plans for labor and development became implicated in questions of intraregional mobility. Part II examines cases 
in which northerners crossed district boundaries to avoid labor demands. Only occasionally did the terms of debate among officials reach the self-importance of Cardinall's concerns about "freedom." Much more commonly, officials worried about maintaining the infrastructure of rule, pleasing their superiors, and cloaking their practices in the terms of colonial trusteeship. Throughout, northerners forced colonial officials to treat labor not just as something that could be extracted from bodies, but also as a political act involving subjects, chiefs, and officials.

Part III continues with a discussion of the early 1930s, when signers of the International Labour Organization's Forced Labour Convention formalized exceptions for labor that was demanded in the "direct interest of the community" or constituted "minor communal services."10 Far from eliminating demands for unpaid labor, these initiatives increasingly enshrined them in emerging practices of development. ${ }^{11}$ By viewing these changes against the backdrop of pervasive local resistance and growing debates over migration, this article shows that officials were well aware of intense struggles among chiefs, administrators, and constituents over the boundaries of communities and the definition of their interests. In reaffirming the idea of "communal interest," officials not only relegitimized the use of forced labor, but also washed their hands of the politics of raising it.

Since the 1970s, scholars have explored how demands for labor and a lack of colonial investment in northern Ghana resulted in the "underdevelopment" or "non-development" of the region. ${ }^{12}$ While northern Ghana's marginality in colonial planning was profoundly important to its long-term economic trajectory, it did not make the region any less the object of colonial developmentalism. Jeff Grischow illuminates how successive colonial administrations came to cast the North's hinterland status as a virtue, particularly in contrast to what they saw as the "uncontrolled" or "premature" development of the southern economy and politics. This framework allowed officials to layer successive visions of change on top of "invo[cations] of community ... to maintain state power while exploiting the resources of the colonies."13

The observation that development planning was important even in zones of underdevelopment reflects what scholars have long identified as the "marvelous ambiguity of the word development," to alternately denote a naturalized process, an idealized model of change, a goal of state policy, and a justification for state intervention to achieve it. ${ }^{14}$ This article approaches development as an emerging framework for intervention in the daily lives of colonial subjects, particularly as it related to building the infrastructure that supported colonial administrative and economic planning. Throughout the interwar period, demands for forced labor were the key practical manifestation of colonial incursion in the Northern Territories, and over the period they came to be justified as part of colonial "development" and, ultimately, as in the "interest of the community." Studies of forced labor in Ghana and elsewhere have often focused on high-profile projects for infrastructure and development and on the use of forced labor for private interest. ${ }^{15}$ In contrast, this article shows that, even in 
times and places where funding was sparse - and perhaps particularly in these cases-unpaid labor became a central component of emerging colonial developmentalism.

\section{Part I: Administration, Forced Labor, and Development, 1920-1930}

British conquest of what became the Gold Coast's Northern Territories Protectorate was a largely speculative and strategic endeavor. ${ }^{16}$ Direct taxation quickly proved impractical, and in 1907 the colonial government eliminated tolls on the caravan trade, the only revenue stream that made significant contributions to the Northern Territories' budget. ${ }^{17}$ Thus, when civilian staff replaced military officers in 1907, they faced a strict colonial unwillingness to expend resources on the region - a sentiment notably captured by Governor Thornburn's 1912 statement that "the Northern Territories must be content to wait their turn" in favor of government investment in the South. ${ }^{18}$

In lieu of taxation, the Northern Territories administration turned to placing demands directly on the bodies of northern men and women. In addition to demanding northern labor for large-scale infrastructure projects in the South, officials required local labor to satisfy DCs' constant preoccupation with 'trekking" through large districts. ${ }^{19}$ Northerners were ordered to clear and clean roads that ran between district capitals, that served as boundaries between districts, and that gave officials access to towns and villages they wished to visit. Northerners built rest houses for officials, and, before the widespread use of official motorcars in the 1920s, DCs on tour had an almost inexhaustible demand for "carriers" (head porters). ${ }^{20}$ Road labor quotas were officially set at six days per quarter for adult men, though demands varied in practice over time and space and women as well as men were targeted. Demands for carriers and rest house buildings were officially sanctioned, but there was no set quota or limit on these impositions.

The history of enslavement in the region provided official rationale for colonial labor demands, which were cast as an extension of tributary relationships that, officials argued, had been disrupted by slave raiding and imperial conquest by Asante, Babatu, and then the British. This vision led officials to turn a blind eye to domestic slavery in a broad sense and to further classify various forms of labor exploitation by chiefs as forms of taxation. ${ }^{21}$ Imagining that northerners had long been a source of coerced labor, colonial officials argued that the colonial state and its agents were the legitimate beneficiaries. Despite this rhetoric, administrators prioritized meeting the essential goals of colonial administration over understanding existing hierarchies, and officials recognized the authority of a variety of earth priests, chiefs, and local strongmen. Officials were more than willing to unseat chiefs who failed to meet administrative demands and, conversely, to support appointed "sergeant major chiefs" who often appeared to be nothing more than hired guns. ${ }^{22}$

Northern officials had tremendous autonomy and very few resources. Between 1908 and 1930, the total number of DCs and clerks in the Northern 
Territories was between twenty and twenty-seven, creating a ratio of one official to nearly thirty-five thousand residents and an area of nearly two thousand square miles. ${ }^{23}$ At the discretion of individual DCs, demands for labor were arbitrary, sporadic, and highly localized. ${ }^{24}$ As administrators shuffled among districts, labor regimes could change dramatically and unpredictably. Latitude for official violence was profound, but the practical extent of enforcement was consistently limited. Lawra-Tumu and Navrongo-Zuarungu, two Northern Province districts, present the range of administrative demands and tactics that were established by 1920, highlighting northerners' well-developed methods of avoidance and resistance. DCs, like chiefs, grappled with the threats to colonial authority presented when northerners refused to "follow" designated chiefs and colonial officials.

From January to November of 1919, A.W. Cardinall was the District Commissioner of the Navrongo-Zuarungu District. ${ }^{25}$ Cardinall's daily records, written while he was working on his first book, The Natives of the Northern Territories of the Gold Coast, reflect his particular mixture of scholarly interest, high-minded ideas about transforming the region, and practical recognition of how administrative demands burdened colonial chiefs. ${ }^{26}$ The most common notes in his records concern the constant complaints from chiefs that locals would not "follow" them. He wrote that this was "a complaint of much elasticity of meaning" and, later, that "follow" is a word I have never understood." 27 In his struggle to understand what chiefs meant by "follow," Cardinall began to recognize that chiefs were using the complaint not as a commentary on the general state of their authority, but instead to explain and excuse their difficulties raising forced labor.

As administrators and chiefs attempted to enforce colonial demands, they faced the limits and contradictions of colonial policy in this administrative hinterland. Cardinall alternated between critiquing Britain for undercutting its own rhetoric of "democracy," and writing longingly of the ways a "benevolent despot" would be able to realize what he saw as the agricultural and trade potential of the region. ${ }^{28} \mathrm{He}$ often concluded such scholarly and ideological musings with more practical recognition that administrators did not need to concern themselves with the workings of authority as much as they simply needed northerners to meet colonial requirements. "From an administrative point of view," he wrote in July, "it matters little whom they 'follow' as long as law and order is observed." 29

In November of 1919, just prior to the yearly demand for dry season labor (from December to March), Cardinall was replaced by W.E. Gilbert, a thirty-four-year-old recruit who came directly from his military service in the First World War. ${ }^{30}$ Over the eight months that Gilbert worked in Navrongo-Zuarungu, he saw with fresh eyes the extent of local resistance to forced labor. Gilbert's responses highlight how administrators used the available tools of colonial administration to respond. While on "trek," Gilbert's usual practice was to stop in a town and note the condition of the roads and rest house under a chief's jurisdiction. He then spoke (through an interpreter) 
to the chief. Nearly everywhere he stopped, Gilbert fielded complaints that certain sections or towns had refused to "follow" chiefs with respect to forced labor. Consulting his lists of villages, Gilbert determined whether the chief had jurisdiction over the area mentioned and, if so, arrested the headmen he found responsible and imposed collective or individual fines.

Speaking to elderly people in the area in the 1990s, Allman and Parker found that memories of violence, punishment, and its threat pervaded narrations of forced labor in the first decades of colonial administration, when government-recognized chiefs found their work crystalizing around the role of labor recruiter. ${ }^{31}$ Some hints of violence and its threat appear even in the selfreported diaries of officials. Gilbert noted the "Maxim Gun for this Station" when it was returned from Tamale, and when he turned the post over to his successor in July of 1920, he described the process as "handing over the books and ammunition." ${ }^{32}$

Fines, imprisonment, and the threat of violence were the constant tools of colonial administration, but it is important to remember that the extent of official intervention was often limited. For many chiefs, most of the time, complaints of "not being followed" could explain months in which colonial rule had been more or less ignored and cast vague, collective blame that resulted, at most, in the punishment of a few. Colonial officials often hesitated before challenging local leaders who seemed to have authority. In a series of complaints between 1919 and 1920, successive DCs noted persistent refusals of labor and loyalty by followers of Anam, the chief of Yoragu, just outside the town of Bolgatanga. Despite being fined and imprisoned, officials were loath to unseat a chief who had the power to organize constituents, even though they concluded he was "doubtless at the bottom of all the trouble in this part of the District." "33

Monthly diaries suggest that at times officials, like chiefs, were drawn into the complex process of coercing labor. In July of 1920, Navrongo-Zuarungu DC Freeman was required to supply railway labor for the South. At first, recruitment seemed simple. Between August 25 and 26, more than three hundred recruits reported to Freeman's office, and he had "to stop now on account of literally having no more money to subsist any more people." ${ }^{34}$ Given the growing popularity of labor migration to cocoa farms in the South, an opportunity to be boarded by the government en route may have seemed an attractive option. ${ }^{35} \mathrm{~A}$ month later, however, Freeman began to report on the widespread return of recruited laborers, listing complaints about the road, the difficulty of getting work and pay, and the nature of the work itself. ${ }^{36}$ Despite Freeman's attempts to "make an example of" particular chiefs and imposing fines for "obstructing recruiting," he ended up simply paying extra travel money for laborers to return south. ${ }^{37}$

Across the Sisilli River from Navrongo-Zuarungu, in the Lawra-Tumu District, forced labor demands were particularly onerous. Between June and August of 1920, C.B. Shields was posted to the sparsely populated eastern (Tumu) side of the district to make residents build and maintain the hundreds of miles of roads that connected the area to the more densely populated 
regions to the west and north. A young official named A.C. Duncan-Johnstone was called in to recruit railway laborers from the western (Lawra) side before taking over the whole district in September. Their diaries show that even when officials aimed for mass recruitment, they faced the limits of their control.

Shields spent three months trying to force constituents to quickly build and improve the main roads leading from Tumu to the western towns of Nandom and $\mathrm{Wa}$, to the French border to the north, and to the boundary with Navrongo-Zuarungu district to the east. He noted the urgency and scope of the demand, writing that "the present road scheme" called for "every available man" to be put to work. ${ }^{38}$ His frustrations with constituent resistance are clear. On the first day of a tour, he remarked that inspecting roads made him "furiously angry ... the only way to get anything proper is to stand all day and watch every inch of it." In one of the roads near Tumu, Shields found that a constable had "taken it into his head that there should be a ... bulk across the road ... it will take 20 men all day tomorrow to unmake it." In Pina, "nothing has been done on ... the road that I wanted, but some that I did not want has been done." In Dolbizan, where a "[c]onstable could only raise 19 men" of the 100 that Shields had demanded, he found that they had "done a little work, where it was already very good and left all bad places." In Jeffisi, he found that constituents had spent " 20 days messing up the road where it was already good." 39

For a brief period, direct supervision and threat of force allowed DCs like Shields to meet administrative demands for road labor. Returning along these roads late in the month, Shields paused to count the hundreds of workers on each section, and "stopped" to "speed things up" where necessary. ${ }^{40}$ By August, when Shields was nearing the end of his term at Tumu, he had concluded, "In the future unless I can be there personally I shall not start any work." 41 In October, when Duncan-Johnstone took over as DC of both Tumu and Lawra, he observed the aftermath of Shields' work. It was an uneven landscape. The residents of Golu, taken with their chief to work on the road to the east of town, had left "a very bad piece of road" on the western road leading to Tumu. At Pullima the road was "as good as anything in the LORHA district," and in Bellu, a site of frustration for Shields, he remarked, "Not only have [constituents] turned out in large numbers, but they have done very excellent work, and from what I saw of the crowds on the road today, seem to be most cheerful, the work being performed to much singing and dancing." The same day, he noted that he could "not say the same for the DASIMA division ... they have done very little work and very few people have turned out."42

More striking than the variation in the work itself was Duncan-Johnstone's sense that he had little control over the practice or politics that created such stark local differences. In August, after reporting on longstanding recruitment issues in the town of Ulu, Duncan-Johnstone reflected on his limits by ruefully quoting a 1911 poem called "The Passive Resister" by an administrator in Nigeria. The chosen passage read, "Of course it's all right if he means to fight/You can easily burst his bubble./But if he sits tight, then it's hell's 
delight/He can give a whole world of trouble." ${ }^{\text {43 }}$ In subsequent months, DuncanJohnstone began to report the surprising fact that some chiefs had taken up road-widening and local road construction "by themselves" or on their "own initiative." $" 44$ The northern administration was pleased, even if Duncan-Johnstone knew little about how or why chiefs had suddenly found road building to serve their economic, personal, or administrative purposes.

Despite the continuation of limited oversight and even more limited budgets, over the course of the 1920s officials began to more seriously consider the future of northern economic change. Demands for long-distance labor competed with hopes for agricultural transformation in the region, as DCs and chiefs alike feared the practical and ideological implications of young men's journeys to the South. Officials recognized that even local demands for carriers, road laborers, and construction projects threatened to disrupt food production in the region, raising the specter not only of suppressed export production, but also of more basic subsistence crises. ${ }^{45}$ By the 1930s, political action and African accumulation in the South allowed administrators to reconceive smallscale food production as a path to development that would avoid the perceived threat of "uncontrolled" development. ${ }^{46}$

In 1919, Gold Coast Governor Frederick Gordon Guggisberg released a ten-year development plan for the colony, the first of its kind in British colonial Africa. ${ }^{47}$ Guggisberg's plans for growth focused primarily on the South, but the plan also articulated a vision for longer-term growth in northern agriculture, education, social welfare, and infrastructure. Transport was both the literal and figurative instrument for this transformation-as planners envisioned an extension of the railway (and later, the road network) as the "Highway of Progress" for the North. ${ }^{48}$ Throughout the decade, northern officials continued apace in their labor demands. The "highway of progress," it seemed, would be an unpaved road, requiring annual maintenance by unpaid labor. ${ }^{49}$ Meanwhile, as chiefs gained experience with labor recruitment, officials redefined road building as part of chiefs' rights to labor for so-called "communal" or "public" purposes.

The rise of motorized transport combined with the newly technocratic interests of the colonial government to create a new set of labor demands on northerners as well as a new set of rationales and staff to implement them. DCs became concerned with the technical requirements of motor transport, and allocated scarce resources to hire road overseers and contractors and to offer nominal payments to forced labor gangs. Demand for "carriers" decreased dramatically by the mid-1920s as DCs began to tour by automobile. ${ }^{50}$ At the same time, DCs' motorcars changed the frequency and pattern of interactions with northerners, with trips that used to take over a week now being completed in less than a day. ${ }^{51}$ By the late 1920 s, DC diaries reported nearly constant visits to the motorcar-accessible towns under their jurisdiction.

In the 1920s, the sudden appearance of private lorry transport had, at best, limited effects on the value northerners saw in roads. ${ }^{52}$ It is certain, however, that it had a negative influence on the experience of unpaid road labor, as 
lorry traffic took a heavy toll on unpaved roads, increasing the frequency with which constituents were called for repairs. ${ }^{53}$ Making roads accessible to motor vehicles without spending much money also spurred additional schemes. ${ }^{54}$ In June to July of 1926, Northern Provincial Commissioner P.F. Whittall began to experiment with local manufacture of road-making materials. Ordering the laborers at his station in Navrongo to make a kiln out of an old government bungalow, he then had them pack it with clay-and-earth bricks to use on local culverts and bridges. While Whittall seems to have paid the staff at his station, the brick-making scheme relied on forced labor, recruited and enforced by colonial staff. ${ }^{55}$

Administrators adapted old methods to the new tools and demands of developmentalist administration. At the height of the rains, DCs in motorcars monitored the effects of water on roads and bridges, noting the improvements that would need to be made. Then, as the rains began to ebb, the real work began. In October of 1926, Whittall recounted his varied practices for controlling unpaid labor. On October 2, he sent a contractor, Abudulai, to oversee both paid and unpaid labor on the main Tamale-Navrongo road. On October 7, Whittall asked the chief of Sandema to initiate and supervise construction of a "dry-weather motor-track" connecting his jurisdiction to the main road, reporting the chief's assurance that "the work can be done without any trouble at all." On the twelfth, Whittall went to visit the DC of South Mamprusi as he supervised construction of a low-cost bridge over the White Volta River, checking up on Abudulai's work on the way home. Back in his headquarters, Whittall arranged for a special road to be made so that the governor could visit a government cattle kraal by motorcar, and reported on the success of his brick-making scheme and its promise for future roadwork. ${ }^{56}$

Meanwhile, resistance to labor demands continued. In the Wa district, for example, DC Sumner complained consistently from 1926 to 1928 about "refusals." In response, he turned to the toolkit of punishments, fines, and oversight forged by his colleagues in the early 1920s - "raising a big row" (August 1926), issuing fines, and assigning extra work as punishment (June 1926, September 1928, October 1928), arresting compound heads (October 1928), and using orderlies and constables to "put the fear of the DC" into recalcitrant workers (October 1928). ${ }^{57}$

By the mid-1920s, colonial reliance on forced labor had become the focus of international as well as local critique. The "Slavery Convention" passed by the League of Nations in 1926 highlighted new European debates about when colonial forced labor constituted "conditions analogous to slavery." As Suzanne Miers and Frederick Cooper have each argued, British and international advocacy on the subject of forced labor relied on drawing distinctions between forced labor for private enterprise, which was condemned, and for public works, which would simply need to be regulated. Furthermore, and particularly important in light of their reliance on chiefs, the British successfully advocated for the retention of labor demanded by "native custom" and in "personal service" to chiefs who were otherwise not compensated for their administrative work. ${ }^{58}$ 
As chiefs gained greater experience with labor recruitment, DCs began to report more cases like those seen by Duncan-Johnstone in 1920, in which chiefs started road and bridge projects on their "own initiative." Official interpretations of "native custom" allowed for administrators to sanction such "initiative" as an extension of chiefs" rights to demand "labor and personal services" from residents in their jurisdiction. In this interpretation, administrators were charged with regulating the extent and limits of these demands. ${ }^{59}$ The case of Kayani, the chief of Tugu, reveals the slim distance between charges of slavery and the justification of forced labor for public works.

Kayani entered district reports in 1920, when Duncan-Johnstone reported that the chief could make "roads without assistance." The DC supported Kayani by punishing "malcontents" who refused to follow the chief. ${ }^{60}$ Six years later, Kayani continued to meet new demands for motorable roads. In December of 1926, the DC of Lawra-Tumu reported that Kayani and the chief of Nandom had both built "excellent" roads and bridges "without help or supervision," praised Kayani's bridge as "show[ing] up any other work on roads in the district," and remarked that "the Public Works Department could take a lesson from the job of work." 61 Concerns about chiefly accumulation in the 1920s, however, made officials inquire more deeply into chiefs' control over labor. Just eight months after the glowing reports of Kayani's roads, a broader investigation into chiefly affairs in the area raised official concern about his ability to exploit constituent labor for his own farms. DC Eyre-Smith reported that Kayani was "using the people in his villages as his slaves." 62

Eyre-Smith's invocation of "slavery" relied on the argument that Kayani's demands for "personal services" were excessive and presented a threat to the economic and political stability of the area. Eyre-Smith speculated that flight from the district and competing demands on constituent time had led to depopulation, agricultural stress, and starvation. He went on to argue that colonial labor demands had provided Kayani with excuses to punish his opponents throughout the 1920s. ${ }^{63}$ In response, Kayani was removed from his chieftaincy in October of 1927. His compound was demolished, his farms were seized, and he was sentenced to six months in prison in Tamale. (He was allowed to return to "live quietly" in Tugu in February of 1928.) ${ }^{64}$

Crucially, the critique of Kayani's practices did not extend to his ability to raise labor "on his own initiative" for roads and other "public" purposes. By April of 1930, the new DC of Lawra-Tumu complained that Kayani's replacement was failing on just this front, as constituents refused to work and "ran "for bush" when the DC summoned them. Arguing that the administration needed "a man with a heavy hand [to be] installed as chief," he advocated that the administration turn, again, to Kayani. ${ }^{65}$ When the DC was instructed to find a "definite charge" against the current Tugu chief to justify his removal, he turned to the administration's new developmental structures, charging him with halting new locust control efforts as soon as military officials left town. ${ }^{66}$ In June of 1930, Northern Provincial Commissioner Whittall approved Kayani's reinstatement as chief of Tugu. ${ }^{67}$ 


\section{Part II: Negotiating Mobility as Resistance}

When faced with constituents' refusals of roadwork, DCs turned to the tools of colonial punishment: fines, imprisonment, violence, and unseating chiefs. When chiefs could recruit labor "on their own initiative," officials defined roads as in the public interest and asked few questions about how labor was raised. This section considers cases in which intraregional migration, in contrast, garnered outsized attention from northern officials. The ability of even small groups of northerners to cross out of a DC's jurisdiction presented new challenges to state coercion. In these cases, DCs became the leaders that constituents refused to "follow." As a result, government demands drew officials, like chiefs, into the politics of forced labor.

In January of 1919, Michael Dasent, then DC of Tumu, visited Santejan, a chiefly jurisdiction on the district's far eastern border. Stopping in the town of Gwosi, he reported that residents had refused to do road and rest house work and, it was suggested, had burned down the commissioner's stables in protest. When the Santejan chief said that "he could never get labor and that they took no notice when he told them to clean the road," Dasent moved through his arsenal for enforcing labor demands. After the Santejan chief fined the town ten sheep, Dasent "addressed" them "on the subject of their evil ways," replaced the Gwosi chief, and stationed a constable in the town. These reports occasioned no comment from Dasent's superiors. The Santejan chief made similar complaints about the people of Kalarsi and Nbenya but then made an allegation that would become a major source of administrative anxiety. He reported that the residents of Nbenya had not only refused to work but were, in addition, "migrating to the Navarro District." 68

The following month, Dasent's replacement, E.O. Rake, sent an inquiry to Northwestern Provincial Commissioner H.M. Berkeley about the Santejan case. Reporting that "the people of a village called NAMANEA [Nbenya] ... have crossed over into the NAVARO district, their complaint being that there was too much work in this District," Rake pointed out that while he was "of the opinion that a native is allowed full liberty in choosing his place of residence," he knew that policies might differ at his new post and asked "what steps" might be necessary "to get these men back." 69

Over the next ten months, Rake's inquiry sparked debate over the relationships among colonial labor demands, administrative control, and competing plans for agriculture and infrastructure. While they were couched in terms of competing principles of "freedom" and "authority," these debates expose competitions among administrators to keep potential laborers within their jurisdiction. In 1919, the boundary between Lawra-Tumu and Navrongo-Zuarungu districts also separated the Northeastern and Northwestern Provinces. Berkeley wrote to his counterpart in the Northeastern Province with the seemingly straightforward request that he "instruct" the DC of Navrongo-Zuarungu to "send these people back." "They ran away to avoid work when called upon by their Chief," he argued, and "if this is allowed ... [t]he people [would] 
desert from one side or the other according to the way they are called upon to supply labour."70

Berkeley and Rake's counterparts in the Northeastern Province, however, saw things differently. Provincial Commissioner S.D. Nash and DC A.W. Cardinall both displayed an early interest in northern small-scale agriculture and began to craft an argument against "interfering with free migration," if "the natives ... have changed their residence merely to get better farming land." 71 Cardinall moved from the specific to the general, raising the "grave issues" that began this article. He questioned the rights of chiefs and the colonial government to place this kind of restriction on local migration. Nash sent a curt note back to Berkeley stating that he would take no action against the migrants. ${ }^{72}$ When Berkeley turned the case over to Chief Commissioner H.W. Leigh, he contrasted Nash and Cardinall's defense of "freedom" with fundamental concerns for authority and respect, calling the migration "a deliberate attempt to scorn the head chief and so the District Commissioner."73

The letters between Nash and Berkeley reveal the administrative pressures and competitions that undergirded the high-minded debates between "freedom" and "authority." Tumu, where DC Shields was about to undertake his major push for road construction, was sparsely populated. Recognizing the reality of widespread discontent among northerners asked to labor in the district, Berkeley sought to use district boundaries to set a limit on residents' options for avoidance. In contrast, Nash and Cardinall, seeing migration as a benefit to agricultural production and labor supply on their side of the boundary, had every reason to defend freedom of movement. ${ }^{74}$ Over the subsequent years, debates between Lawra-Tumu and Navrongo-Zuarungu became more entrenched, even as the northern administration shuffled officials among districts. ${ }^{75}$ Like the chiefs to whom they delegated the task of raising labor, DCs found that competition for "followers" could be fierce.

By 1924, as officials in Lawra-Tumu began to complain of additional outmigration to neighboring districts, the chief commissioner came up with an ad hoc solution that satisfied no one. He required migrants to return to Tumu to fulfill their annual quota of road labor, regardless of where they currently resided. ${ }^{76}$ In July 1925, Austin-Cathrie, DC on the Navrongo side of the boundary, recounted that a headman "at once jumped up and said he did not mind strangers settling on his land but he would expect them to pull their weight on his portion of road work." A neighboring chief feared that demanding labor from "people [who were] deserting" to another jurisdiction would "cause trouble" between him and the host chief. ${ }^{77}$

Officials likewise fretted over the consequences of a scheme that would make one DC in charge of either the labor or roadwork from another's jurisdiction. After years of supervising labor, they knew the work would only involve them in local politics and, they feared, cause conflict with other DCs. Abandoning the plan, a new chief commissioner summarized its hopelessness, arguing that the DC of Navrongo-Zuarungu had done "all he can do to cope with the roads in his own District." 78 Given the well-established resistance 
that northerners had given to colonial practice, "coping" with their road quotas was as much as DCs could do.

In the midst of trying to stop northerners from migrating between districts to avoid forced labor, officials began to encourage it in the interests of agricultural development. In April of 1923, Chief Commissioner Leigh proposed the first tentative plans to resettle northerners from both Lawra-Tumu and Navrongo-Zuarungu districts to the "more thinly populated South" of the region, in the Gonja and South Mamprusi districts. ${ }^{79} \mathrm{He}$ instructed officials to "endeavor to get 5 good families from the environment of NAVRONGO to come down," promising each "family" ten pounds from the newly established Northern Territories Development Fund and one thousand seed yams for planting. Recognizing the potential deterrent presented by increased labor burdens in less populated areas, he specified that, "these people are not to be called on for communal labor for two years." 80 Leigh's idea, which later became known as the "Abangabisi Migration Scheme," also became embroiled in the politics of labor. Here, development schemes became an opportunity for a small number of constituents to gain recognition of their complaints against a chief and to secure official reprieve from the labor demands of the state.

Leigh's initial plan did not come to fruition. After a flurry of protest from Cardinall about the legality of such a scheme, officials found that they had no interested migrants in the first place. The idea was left dormant until 1928, when it was given new life by early plans for regional agricultural development that saw the southeastern portion of Northern Province as a place of agricultural opportunity. In the late 1920s and 1930s, concerns about "overpopulation" in the far north combined with an emerging interest in supporting small-scale agriculture, rather than a singular focus on export production. ${ }^{81}$ Given the preceding decade of debate over interdistrict migration, officials clearly recognized that intraregional mobility was already established practice. ${ }^{82}$ They nevertheless envisioned that colonial direction was needed to shape and control mobility.

Northern Provincal Commissioner Whittall argued that promoting migration of the kind that was already common would "gain the confidence of the natives over this question of migration." The "question," it seems, was less about migration itself than about the risks of working with the state. "Once their fears ... are overcome by seeing that it can be done without any harm coming to them," he argued, "then we might get greater numbers to move farther a-field." 83 The Abangabisi Scheme thus anticipated later plans for resettlement tied to tsetse eradication in the $1940 \mathrm{~s}$, when attempts to resettle groups of five hundred to two thousand people were commonly tried. Both of these efforts were then dwarfed by plans to resettle populations to the uncultivated lands of the Gonja District, culminating in the attempt to transform the area into a zone of export production during the Gonja Development Scheme in the 1950s. ${ }^{84}$

In December, Cardinall filled in as Northern Provincial Commissioner. He saw the migration scheme as an opportunity to solve a longstanding dispute in his old district. "On my arrival here in December [1928], I found that the age-old quarrel at YORAGU was still alive," Cardinall explained to his superiors. "[I]t 
seemed to me that a settlement of this dispute would be attained if the discontented were to move." 85 The "discontented" were constituents living outside of Bolgatanga who administrators called "the Abangabisi." First noted in the early 1920 s, this group of people had been involved in a long-running effort to switch their allegiance to Anam, the chief of Yoragu who had so frustrated DCs like Cardinall throughout the decade. ${ }^{86}$ It was the kind of dispute over whom northerners would "follow" that DCs despised, and Cardinall's plan seemed to kill two birds with one stone.

By 1929, ambitions for the scheme were high, with administrators estimating the movement of seventy-five compounds and a total of fifteen hundred people. ${ }^{87}$ Instead, the scheme became a narrow opportunity for a group of northerners to contest the demands of forced labor by putting themselves in jurisdictional limbo. As the Northern Territories administration dispatched a geologist to report on "possible sites for new villages" and worked out the details of the scheme (including the perpetual question of cash payments), officials raised the question of whom the migrants would "follow" once they settled. Rather than requiring the migrants to follow a divisional or village chief - particularly one that would bristle at the prohibition on demanding forced laborthe migrants were authorized to follow the government-recognized Mamprusi king. ${ }^{88}$ Beyond the initial promise of two years' reprieve from forced labor, officials recognized that when the Mamprusi king offered such arrangements to discontented northerners, it became impossible for local chiefs to enforce colonial labor demands. ${ }^{89}$

Even as Chief Commissioner Leigh reported proudly in June of 1929 that some "eleven hundred people of all ages" had already moved in accordance with the scheme, the Northern Provincial Commissioner and DCs of Zuarungu and South Mamprusi struggled to find out how many migrants had "really" migrated and how many were simply crossing borders to avoid farm clearing or their "24 days" of road labor. ${ }^{90}$ By January of 1930 , pressed yet again to ascertain the "real intent" of potential migrants, the DC of South Mamprusi lamented that "these people [the Abangabisi migrants] have chopped and changed about so much that I would never be certain." ${ }^{11}$ In the end, a mere three compounds were ever determined to have "really" relocated, and the DC of South Mamprusi requested nine pounds to compensate them. ${ }^{92}$ As an early colonial development scheme, the Abangabisi scheme was a colossal failure. For the migrants, however, the scheme had given official recognition to their complaints against a chief and had, most importantly, allowed them to secure an official exemption from forced labor demands. Having spent a decade attempting to prevent northerners from avoiding labor by voting with their feet, northern officials found themselves sponsoring just such a strategy.

\section{Part III: Debates over “Community," Labor, and Force in the 1930s}

In 1930, the British administration in the Gold Coast issued a "memorandum on Forced Labour" that sought to begin to bring the colony's laws in alignment with 
the International Labour Organization's Forced Labour Convention, which was to come into force in $1932 .{ }^{93}$ In the Northern Territories Protectorate, as Chief Commissioner Jackson noted, any legislation on forced labor would affect policy much more than in the South. ${ }^{94}$ Between 1930 and 1935, as officials debated the extent to which systems of unpaid labor could remain at the center of colonial practice, they worked with fuzzy international definitions of "community" and attempted to parse the differences among coercion, voluntarism, and local taxation in-kind.

The Convention outlined two classes of rationale by which colonial officials could continue to demand unpaid labor. Article 2 of the Convention specified outright exceptions to the ban: (1) "compulsory military service"; (2) "normal civic obligations"; (3) "a conviction in a court of law"; (4) "cases of emergency"; and (5) "minor communal services performed by members of a community and in the direct interest of the community." 95 Article 10 elaborated additional cases where forced labor "exacted as a tax ... for the execution of public works by chiefs who exercise administrative functions" would be acceptable, at least for the short term. In these cases, several additional provisions required that such work be, among other things, of "direct interest for the community," that it not impose "too heavy a burden" on this community and that workers would not have to travel long distances or be asked to labor in ways that would interfere with social and religious life or agricultural production. ${ }^{96}$ In the case of labor demanded under Article 10, the convention required that signatories make an annual report about the extent and character of these demands.

When the Convention was first applied in 1932, the colonial government classified unpaid roadwork under Article 10. In November, the chief commissioner of the Northern Territories asked northern officials to report the "extent to which recourse has been had to forced or compulsory labor in your area, purposes for which employed, sickness and death rates, hours of work, methods of payment, and rates of wages," specifying that "compulsory or forced labor means labor employed on roads, rest houses and station buildings which has not offered itself at current labor rates of pay." Replies to this query reveal that officials had come to adopt extremely different definitions of what qualified as "forced labor" in this context. In the Gambaga District, for example, reports for June to September of 1932 included a response by J.K. Syme of Bawku that there had been "no labor" called upon, an estimate from Gibbs in South Mamprusi/Zuarungu that 170 laborers had worked for one week, and the rather remarkable report from Olivier in Navrongo that thirtythree thousand people had worked for six days each, at a total cost of eleven pounds and ten shillings. ${ }^{97}$

One year into the application of the convention, British officials began to reinterpret the law in response to their inability or unwillingness to classify, quantify, and challenge the widespread colonial dependence on forced labor. In a lengthy memo on "Maintenance of Roads Under the Forced Labour Convention," Acting Colonial Secretary G.C. du Boulay explained the 
change, first pointing out that estimates had now been prepared that foresaw the "eventual cost to this Government" of substituting paid road labor under Article 10 to be "some $£ 140,000$ a year." Citing "subsequent correspondence received from the Secretary of State," du Boulay explained that "it appears that the view taken by this Government ... was rather too rigid" and that the Colonial Office had issued a ruling that "in the majority of the dependencies in Africa the maintenance of minor local roads and tracks is regarded as a minor communal service" that would be exempt from forced labor bans under Article 2. Under this ruling, the colonial government outlined a three-tiered system of road classification. After designating a handful of "Class A-arterial and main roads" that would be maintained by the public works department, the administration then asked each regional commissioner to classify most other roads as "Class C-local roads" that "exist solely for the benefit of the local community" and that colonial officials could therefore "requir[e] villages to maintain." 98

Between 1933 and 1935, northern DCs debated which, if any, of the roads in the Northern Province could be classified as class C "local roads and tracks" under a definition that hinged on the idea of "the benefit of the local community." The staunchest opponent of this classification was W.J.A. Jones, one of the principal architects of indirect rule in the North. Having served as the secretary for native affairs in Accra between 1929 and 1933, Jones was posted as the chief commissioner of the Northern Territories in $1933 .{ }^{99}$ In a series of letters to his superiors, Jones highlighted the patent absurdity of classifying northern roads as having purely "local" benefits. He pointed out that " 2,070 miles of motorable roads in the Protectorate ... were originally constructed by the people at little or no cost to Government," and that under the new scheme more than eighteen hundred of these miles would have to be maintained locally. ${ }^{100}$

Jones pointed out that, in sparsely populated areas like Tumu, roadwork had often required northerners to labor far from home. He drew on the experiences of officials to highlight the inefficiency of requiring forced labor, arguing that "compulsory labor is a form of taxation and, as all District Commissioners have observed, an inequitable form in that it is evaded by a large number. It is also wasteful of labor as of those who attend only a small percentage do more than an hour's work in a day." ${ }^{101}$ Instead, he proposed that the central government dedicate the relatively large sum of seventy-five hundred pounds a year to pay road laborers. ${ }^{102}$ After more than a decade of experience with attempts to enforce local road labor demands, Jones's memos resonated with district officials. In Navrongo-Zuarungu, for example, officials found that only fifteen miles of the road from Navrongo to Lawra could "easily be maintained as a Class C road."103

Jones's attack on the classification of roadwork, however, relied on an affirmation that other forms of labor, especially for more "local" infrastructure and services like dams and wells, fell firmly in the category of "minor communal services." In these cases, Jones recommended that officials defer to "native 
customs" in the requirements for labor, arguing, "legislation would convert what is regarded as a social duty to be performed voluntarily into a legal obligation. And there can be no question as to which is the better system." Nevertheless, he recommended that limits be set at the same level as the previous road work quotas, "restricting to twenty-four the number of days on which a person may be required to work during a year." He went on to note that even this would be only a fiction, because "for several years to come, it will be impossible to enforce such a Regulation, as there will be no clerks to keep records."104

It was a loophole through which the northern administration could slide all manner of development demands in the coming years, and officials did so with free legal rein. Just a year later, in May of 1936, the colonial secretary's office attempted to put northern roads back into this category, pointing out that there was "nothing in [the Labour Ordinance No 33 of 1935] to prevent a chief and his people maintaining and clearing any road by mutual consent in accordance with native custom, provided that only voluntary labor is employed."105 By the late 1930s, almost all northern roads existed in this administrative gray area. Lacking funding to pay laborers at market rates, the northern administration left roads to the efforts and whims of individual DCs and chiefs.

\section{Conclusion}

This article has shown that demands for unpaid labor, primarily for colonial road building, defined the experience of interwar colonialism in northern Ghana. Marginal to colonial budgets and development priorities, the northern administration sought to build and maintain the infrastructure of rule by imposing labor demands through local leaders. Many northerners resisted colonial and chiefly demands by simply not doing what was asked. When they did so, they found that the threat of colonial violence was constant, but its imposition was sporadic and often limited in scope. Chiefs could not always compel colonial subjects to act, a reality reflected in their frequent assertions to colonial officials that people refused to "follow" them. Colonial DCs came to understand this dynamic even more intimately when they began to suspect that northerners were using migration between districts as another strategy to escape labor demands. In these cases, DCs became the leaders that northerners refused to "follow." Officials found themselves enmeshed in competitions to secure local labor, a politics they neither understood nor could control.

When the colonial administration began its first plans for infrastructural and agricultural development in the North, they grafted new demands and ideologies onto these existing structures of force and resistance. Motor transportation changed the demand for unpaid labor as well as the mechanisms of enforcement. DCs began to prize chiefs who could construct roads on "their own initiative" - a phenomenon that not only saved money but also allowed them to avoid growing international critiques of forced labor by repackaging it as public service. By the 1930s, as officials negotiated the implementation of the ILO's Forced Labour Convention, they managed to place unpaid labor 
for roads and other works into the murky space that the Convention created for unpaid labor to serve "community" interests. In the 1930s, as plans and funding for development expanded in the Northern Territories, district officials instead used the presence of "communal labor" as a key criterion for granting local development funds. 106

It is difficult to ascertain whether this maneuver increased or decreased the forced labor demands faced by northerners. When administrators officially devolved responsibility to chiefs under indirect rule, both the extent and mechanisms of coercion were largely displaced from the archival record. As DCs became less enmeshed in the local politics of labor, they likely created both new possibilities for and new limits on northern resistance. (As the example of the Abangabisi Migration Scheme suggests, while official attention was usually the quickest route to state violence, it could sometimes open up limited opportunities to avoid labor demands.) What is clear, however, is that the Forced Labour Convention created a legal mechanism for officials to reclassify local resistance. In the interwar years, concern that northerners refused to "follow" chiefs and DCs drew official attention to the local politics of labor. In the late 1930s, official allowance for labor demands in "the communal interest" made resistance to road labor an argument against disbursing colonial development funds. Practices that defined the limits of colonial control became, in the development era, a problem for the "community."

\section{NOTES}

* I would like to thank Benedetta Rossi for her leadership and guidance in the preparation of this special issue. Brian Wood provided invaluable research assistance by identifying relevant passages from several years of district files. I would also like to thank the journal's two anonymous reviewers for their helpful comments and suggestions.

1. Letter from DC A.W. Cardinall to the Acting Commissioner of Northern Province, June 14, 1919, Public Records and Archives Administration, Accra, Ghana (hereafter cited as PRAAD-Accra) ADM56/1/278.

2. Letter from H.M. Berkeley, Commissioner of the Northwestern Province, to H.W. Leigh, Acting Chief Commissioner of the Northern Territories, Oct 27, 1919, PRAAD-Accra ADM56.1.278.

3. Roger Thomas, "Forced Labour in British West Africa: The Case of the Northern Territories of the Gold Coast 1906-1927," Journal of African History 14 (1973): 79-103.

4. N.J.K. Brukum, "Sir Gordon Guggisberg and Socio-Economic Development of Northern Ghana, 1919-1927," Transactions of the Historical Society of Ghana, 9 (2005): 1-15.

5. Carola Lentz, Ethnicity and the Making of History in Northern Ghana (Edinburgh, 2006), 57.

6. Jean Allman and John Parker argue, "Outside of moments of direct coercion, the British presence [in the region] only made a difference in people's daily lives when it was allotted a role in local narratives, that is, when it intersected with local configurations of power." Tongnaab: The History of a West African God (Bloomington, IN, 2005), 91.

7. Some archival material from the Public Records and Archives Administration, Tamale, Ghana (hereafter cited as PRAAD-Tamale) has been digitized and made available through the British Library's Endangered Archives Programme (hereafter cited as EAP) at http://eap.bl.uk. For this material, where possible, I have included the original record number from PRAAD-Tamale followed by the reference from EAP in parentheses. Where an EAP reference is not given, files were accessed in person at PRAAD-Tamale. 
8. Kwabena Opare Akurang-Parry, "Colonial Forced Labor Policies for Road-Building in Southern Ghana and International Anti-Forced Labor Pressures, 1900-1940," African Economic History 28 (2000): 1-25; A. A. Iliasu, "The Establishment of British Administration in Mamprugu, 1898-1937," Transactions of the Historical Society of Ghana 16 (1975): 1-28; Thomas, "Forced Labour."

9. Suzanne Miers, Slavery in the Twentieth Century: The Evolution of a Global Problem (Walnut Creek, CA, 2003), 141-42.

10. International Labour Organization (ILO), Convention CO29, "Forced Labour Convention," June 28, 1930. http://www.ilo.org/dyn/normlex/en/f?p=1000:12100:0::NO:: P12100_ILO_CODE:C029.

11. In his comprehensive treatment of the relationship between British antiforced labor activism and what became known as "communal" labor in Kenya, Opolot Okia convincingly argues that opposition to forced labor on major public works projects like the Uasin-Gishu Railway worked to legitimize other forms of unpaid labor, particularly those that could be rationalized as "communal" duties. See Opolot Okia, Communal Labor in Colonial Kenya: The Legitimization of Coercion, 1912-1930 (New York, 2012), especially chapters 5 and 6.

12. R. B. Bening, "Colonial Development Policy in Northern Ghana 1898-1950," Bulletin of the Ghana Geographical Association 17 (1975): 65-79; Iliasu, "The Establishment of British Administration in Mamprugu"; Nii K. Plange, "Underdevelopment in Northern Ghana: Natural Causes or Colonial Capitalism?" Review of African Political Economy 15/16 (1979): 4-14; Inez Sutton, "Colonial Agricultural Policy: The Non-Development of the Northern Territories of the Gold Coast," International Journal of African Historical Studies 22 (1989): 637-69. Brukum points out that even Guggisberg's explicit statements rejecting previous neglect did not change the fundamental treatment of the region as a labor reserve. See Brukum, "Sir Gordon Guggisberg," 6.

13. Jeffrey Grischow, Shaping Tradition: Civil Society, Community and Development in Colonial Northern Ghana, 1899-1957 (Leiden, 2006), 15-16. Grischow echoes Cowen and Shenton's foundational argument that British "doctrines of development" in the nineteenth and twentieth centuries incorporated the idea of colonial trusteeship in order to make development the object of state policy and to reconcile ideas of progress and of community. M. P. Cowen and R.W. Shenton, Doctrines of Development (London, 2005), chapter 1, especially $53-55$.

14. The quotation is from Frederick Cooper and Randall M. Packard, eds., International Development and the Social Sciences: Essays on the History and Politics of Knowledge (Berkeley, 1997), 4. For longer discussions of development as discourse, ideology, and practice over the course of the nineteenth and twentieth centuries, see Cowen and Shenton, Doctrines of Development and Joseph Morgan Hodge, Triumph of the Expert: Agrarian Doctrines of Development and the Legacies of British Colonialism (Athens, OH, 2007). Depending on the scope of a study and an author's approach, a work on development in Africa can begin in the second half of the nineteenth century, in the 1920s with British and French ideas of state-led development and mise en valeur, or in the acceleration of planning and the addition of metropolitan funding in the period after the Second World War. For articulations of each argument, see, respectively, Hodge, Triumph of the Expert, 1-20; Monica M. Van Beusekom, Negotiating Development: African Farmers and Colonial Experts at the Office Du Niger, 1920-1960 (Heinemann, 2002); and Frederick Cooper, "Writing the History of Development," Journal of Modern European History 8 (2010): 5-23. While sometimes framed as debates about origins, these different perspectives might be better understood as a reflection of development's malleability as a historical and historiographical object.

15. Akurang-Parry, "Colonial Forced Labor Policies"; Iliasu, "The Establishment of British Administration in Mamprugu"; Thomas, "Forced Labour"; Alexander Keese, "Slow Abolition within the Colonial Mind: British and French Debates about 'Vagrancy,' 'African Laziness,' and Forced Labour in West Central and South Central Africa, 1945-1965," International Review of Social History 59 (2014): 377-407; Van Beusekom, Negotiating Development. A prominent recent exception is Benedetta Rossi, From Slavery to Aid: Politics, Labour, and Ecology in the Nigerien Sahel, 1800-2000 (Cambridge, 2015), which highlights the complex relationships among private and state-led practices of forced labor in southern Niger's Ader region over the nineteenth and twentieth centuries. Libbie Freed's work on road building in French Central Africa does excellent work to explore ideologies and practices of forced labor in a low-resource context. See Libbie Freed, "Conduits of Culture and Control: 
Roads in Colonial French Central Africa, 1890-1960" (Ph.D. diss., University of Wisconsin, 2006). For a general survey of the continued legal ambiguities regarding forced labor, see Miers, Slavery in the Twentieth Century.

16. Martin Staniland, The Lions of Dagbon: Political Change in Northern Ghana (Cambridge, 1975), 39; Grischow, Shaping Tradition, 23.

17. Staniland, The Lions of Dagbon, 44.

18. David Kimble, A Political History of Ghana; the Rise of Gold Coast Nationalism, 1850 1928 (Oxford, 1963), 534; Grischow, Shaping Tradition, 47. Staniland quotes an earlier statement from Governor Hodgson in 1899 that not "a single penny more than was absolutely necessary" would be expended on the area. Staniland, The Lions of Dagbon, 43.

19. With much more limited success, officials sporadically recruited labor for southern mines. The North also became a primary site of recruitment for the Gold Coast Regiment during the First World War. For more on the relationships among different demands for forced labor in the South, see Thomas, "Forced Labour," and Roger Thomas, "Military Recruitment in the Gold Coast during the First World War," Cahiers d'Études Africaines 15 (1975): 57-83. For more on forced labor and trekking, see Staniland, The Lions of Dagbon, $45-48$.

20. Staniland notes that 1,344 carriers were recruited in the Western Dagomba district in 1920 , representing what the DC estimated as "ten-thousand man-days" of lost agricultural labor. Staniland, The Lions of Dagbon, 46.

21. Grischow, Shaping Tradition, 31-32. For example, in January of 1919, DC Michael Dasent in Tumu reported that while supervising "improvement" in Tumu town, "The Chief of Tumu has at last realized that it is one of the privileges of a chief to be able to obtain labour for the improvement of his house, which he is now doing." January 1919, Tumu Informal Diary, PRAAD-Tamale NRG8.4.5 (EAP541/1/4/5). While domestic enslavement existed in the Northern Territories, indications are that forced labor recruited by chiefs relied on a variety of relationships of dependence and would have fallen on a variety of constituents. It is unclear from the records exactly how different chiefs raised labor, but there is little indication that enslaved people were a particular target.

22. Ibid., 39. See also Lentz, Ethnicity, chapter 2, 33-71; Allman and Parker, Tongnaab, chapter 2, 72-104.

23. The comparable figures in Ashanti and the Colony were 17,425 people/1,006 square miles and 27,253 people/593 square miles. Staniland, The Lions of Dagbon, 46-47.

24. As Allman and Parker argue, "British administration ... was experienced as brutal, illegitimate, and unpredictable, but it was also encountered unevenly, episodically, and in ways that were often marginal to the rituals and work of daily life." Allman and Parker, Tongnaab, 90.

25. Contemporary spellings varied among Navarro/Navaro/Navoro and Zuaragu/ Zuarugu. Cardinall began his time in the Gold Coast Civil Service as a 27-year-old in 1914 and was first posted to the North in 1916. Staniland offers details of the educational and military background of a number of northern administrators as well as their dates of service in the colony and in the North; see Staniland, The Lions of Dagbon, 48-49.

26. The book was published in 1920. See A. W. Cardinall, The Natives of the Northern Territories of the Gold Coast, Their Customs, Religion and Folklore (London, 1920). Cardinall's district diaries are sporadic and vague in reporting labor recruitment and works construction. In early 1919, he wrote of progress on roads and station buildings, but he also discussed the need to limit labor demands because of the district's heavy losses from the influenza epidemic, which he estimated had killed ten thousand residents by January. In November of 1919, he reported that he preferred "voluntary" and "private" recruiting for railway labor rather than recruitment by DCs. January-November 1919, Navrongo-Zuarungu Informal Diary, PRAAD-Tamale NRG8.4.3 (EAP541/1/4/3).

27. March and October 1919, Navrongo-Zuarungu Informal Diary, PRAAD-Tamale NRG8.4.3 (EAP541/1/4/3).

28. August and September 1919, Navrongo-Zuarungu Informal Diary, PRAAD-Tamale NRG8.4.3 (EAP541/1/4/3). $1 / 4 / 3)$.

29. July 1919, Navrongo-Zuarungu Informal Diary, PRAAD-Tamale NRG8.4.3 (EAP541/

30. Staniland, The Lions of Dagbon, 49. Allman and Parker confirm the months of dry season labor demands: Tongnaab, 60 . 
31. See Allman and Parker, Tongnaab, 86-87.

32. March and July 1920, Navrongo-Zuarungu Informal Diary, PRAAD-Tamale NRG8.4.10 (EAP541/1/4/10).

33. July 1920, Navrongo-Zuarungu Informal Diary, PRAAD-Tamale NRG8.4.10 (EAP541/1/4/10).

34. August 1920, Navrongo-Zuarungu Informal Diary, PRAAD-Tamale NRG8.4.10 (EAP541/1/4/10).

35. The administrative urgency of the trip, however, seems to have heightened the danger of travel. In September, after complaining of the "nuisance" of "dealing with deserters from Railway labor," Freeman relayed the news from two such "deserters" that two men had drowned while trying to cross a flooded road. September 1920, Navrongo-Zuarungu Informal Diary, PRAAD-Tamale NRG8.4.10 (EAP541/1/4/10).

36. When questioned by Freeman, a headman from Bare reported, "The clerk they were handed to said they would have to go underground," which lead his entire gang to refuse the work. October 1920, Navrongo-Zuarungu Informal Diary, PRAAD-Tamale NRG8.4.10 (EAP541/1/4/10). Thomas argues that northern migrants to the mines were often tasked with "the dangerous and unpleasant underground work." See Thomas, "Forced Labour," 80.

37. He reported, for example, that he "collected 46 deserted labourers, paid them extra subsistence and sent them back." October 1920, Navrongo-Zuarungu Informal Diary, PRAAD-Tamale NRG8.4.10 (EAP541/1/4/10). The official terminology of "desertion" and the existence of punishments further confirm that there was little that was "voluntary" about labor recruitment.

38. June 1920, Tumu Informal Diary, PRAAD-Tamale NRG8.4.9 (EAP541/1/4/9). Jeffisi is often "Jeffies" in colonial diaries.

39. July 1920, Tumu Informal Diary, PRAAD-Tamale NRG8.4.9 (EAP541/1/4/9).

40. Ibid.

41. August 1920, Tumu Informal Diary, PRAAD-Tamale NRG8.4.9 (EAP541/1/4/9), remarking on work at Bellu. Shields was transferred to Wa District in August.

42. October 1920, Lawra Informal Diary, PRAAD-Tamale NRG8.4.15 (EAP541/1/4/15).

43. August 1920, Lawra Informal Diary, PRAAD-Tamale NRG8.4.15 (EAP541/1/4/15). The poem is from Adamu (E.C. Adams), Lyra Nigeria (London, 1911). The full text can be found at http://www.archive.org/stream/lyranigeriae00adamiala/lyranigeriae00adamiala djvu.txt.

44. September and October 1920, Lawra Informal Diary, PRAAD-Tamale NRG8.4.15 (EAP541/1/4/15). On September 3, Duncan-Johnstone noted that the chief of Lambussie was observing roads in Lawra to make his own. On September 11, he wrote that the chief of Nandaw was widening his road, and in October he argued that road widening signaled that "all the Chiefs seem keen on making a name for themselves." He also noted in September that the newly installed magajia (women's leader) in Lawra had organized 500 women to do road labor around town.

45. Staniland, The Lions of Dagbon, 52-53.

46. Grischow argues that from the early twentieth century, successive waves of development ideology in the colonial North were consistently conceived by administers as "preserving community." See Grischow, Shaping Tradition.

47. Ibid., 60 .

48. Ibid., 60-61.

49. For an excellent study of automobility in Ghana, including more on the contradictions between ambition and funding in Guggisberg's road building plans, see Jennifer Hart, Ghana on the Go: African Mobility in the Age of Motor Transportation (Bloomington, IN, 2016), chapter 1. For more on the relationship between road labor and French ideologies of mise en valeur in the 1920s, see Freed, "Conduits of Culture and Control: Roads in Colonial French Central Africa, 1890-1960," chapter 2.

50. The Lawra-Tumu District commissioner noted in July 1926 that the district veterinary officer had "travelled 79 days in June Quarter, thus taking some 1000 men for carriers in the height of the farming season," and recommended on this basis that it was "high time he was offered a car allowance." July 1926, Informal Diaries Northern Province, PRAAD-Tamale NRG8.4.18 (EAP541/1/4/18).

51. Staniland, The Lions of Dagbon, $196 \mathrm{n} 33$. 
52. There has been limited research into the development of road transport in northern Ghana, but recent studies by Ntewusu and Soeters suggest that in the 1920s traders began to rely on lorry transport in addition to older methods of transport by canoe, head porters, carts, and bicycles. While lorry transport undoubtedly began to increase the value of roads for those northerners who were involved in long-distance trading, in the 1920s the impact was limited and the vast majority of trade north of Tamale continued to be carried by head-load. See Samuel Ntewusu, "Settling in and Holding On. A Socio-Economic History of Northern Traders and Transporters in Accra's Tudu: 1908-2008" (Ph.D. diss., University of Leiden, 2011), chapter 6; and Sebastiaan Soeters, "Tamale 1907-1957: Between Colonial Trade and Colonial Chieftainship" (Ph.D. diss., University of Leiden, 2012), chapters 2 and 3.

53. Hart points out that "early commercial motor lorries were a poor fit for early twentieth-century road conditions in the Gold Coast. At a time when few roads were metalled [paved] the heavy weight of imported European lorries caused dirt and gravel roads to deteriorate quickly." Hart, Ghana on the Go, 45. For complaints about the impact of lorries on roads, see excerpts from Lawra-Tumu Diary, December 1926, Informal Diaries Northern Province, PRAAD-Tamale NRG8.4.18 (EAP541/1/4/18) and from Mamprusi District Informal Diary, January 1933, Extracts from Informal Diaries of the Commissioner of the Southern Province, PRAAD-Tamale NRG8.4.69 (EAP541/1/4/67).

54. By 1930, Whittall estimated that " 5 or 6 hundred pounds" would be necessary to pay the labor used annually to repair the drifts on the road between Tamale and Navrongo-a laughably large expense for around 100 miles of road. This estimate of the tradeoffs between labor and materials hit at the heart of the financial rationale for road labor. An all-weather road, which would drastically reduce annual labor costs, was, the governor noted, simply out of the question. January 1930, Informal Diary Chief Commissioner Northern Territories, PRAAD-Tamale NRG8.4.33 (EAP 541/1/4/32).

55. In June, Whittall reported that a constable who was supervising carriers delivering clay from the town of Tili (more than forty miles away) had become "annoyed" at one carrier's sickness and had "made them strip and lie down on the stony road and roll along as punishment." June 1926, Northern Provincial Commissioner Diary, Diaries, PRAAD-Tamale (EAP541.1.4.30 pt 1).

56. October 1926, Informal Diaries Northern Province, PRAAD-Tamale NRG8.4.18 (EAP 541/1/4/18).

57. June 1926 and September-October 1928, excerpts from Wa Monthly Informal Diaries, Diaries, PRAAD-Tamale (EAP541.1.4.30 pt 1).

58. Miers, Slavery in the Twentieth Century, chapter 10. Cooper suggests that this distinction in fact legitimized many forms of forced labor: "Whatever was not declared coerced was therefore not analogous to slavery and would acquire the distinction of having been exonerated in terms of the only moral criteria the League and the ILO were applying to colonial labor." Frederick Cooper, "Conditions Analogous to Slavery: Imperialism and Free Labour Ideology in Africa," in Beyond Slavery: Explorations of Race, Labor, and Citizenship in Postemancipation Societies, ed. Frederick Cooper, Thomas C. Holt, and Rebecca J. Scott (Chapel Hill, 2000), 132.

59. When enacted on July 1, 1935, Labour Ordinances for the Gold Coast Colony (Ordinance 21), Ashanti (Ordinance 32), and the Northern Territories (Ordinance 33), explicitly protected chiefly rights to "labour and personal services" in Ashanti and the Northern Territories. Gold Coast, The Laws of the Gold Coast Revised Edition Vol. 1 (Accra, 1937).

60. Duncan-Johnstone's discussions of Tugu roads and Kayani's relationships with constituents appear in the diaries for June, July, August, and September of 1920. The quotation is from September 19, 1920. Lawra Informal Diary, PRAAD-Tamale NRG8.4.15 (EAP541/1/4/15).

61. Extracts from Lawra-Tumu Diary, December 1926, Informal Diaries Northern Province, PRAAD-Tamale NRG8.4.18 (EAP541/1/4/18).

62. Lawra District Files for August and September 1927, Informal Diaries, PRAADTamale NRG8.4.30 (EAP 541/1/4/29). The quotation is from a letter from the District Commissioner of Lawra-Tumu to the Commissioner of the Northern Province on August 23, 1927.

63. Ibid.

64. Correspondence September 1927 to February 1928, Tugu Affairs, PRAAD-Tamale NRG8.2.14 (EAP 541/1/2/10). 
65. Letter from the Acting DC of Lawra-Tumu to the Commissioner of the Northern Province, April 15, 1930, Tugu Affairs, PRAAD-Tamale NRG8.2.14 (EAP 541/1/2/10).

66. Letter from the Commissioner of the Northern Province to the Acting DC of Lawra-Tumu, May 8, 1930, and letter from the Acting DC Lawra-Tumu to the Commissioner of the Northern Province, May 26, 1930, Tugu Affairs, PRAAD-Tamale NRG8.2.14 (EAP $541 / 1 / 2 / 10)$. The exception allowing forced labor in the case of "invasion by animal, insect, or pest," was enshrined in Article 2 of the 1930 ILO Forced Labour Convention. ILO, Convention CO29, "Forced Labour Convention," June 28, 1930. http://www.ilo.org/dyn/ normlex/en/f?p=1000:12100:0::NO::P12100_ILO_CODE:C029.

67. Letter from the Commissioner of Northern Province to the Acting DC of Lawra-Tumu, June 5, 1930, Tugu Affairs, PRAAD-Tamale NRG8.2.14 (EAP 541/1/2/10).

68. January 1919, Tumu Informal Diary, PRAAD-Tamale NRG8.4.5 (EAP541/1/4/5).

69. Letter from E.O. Rake, DC of Tumu, to commissioner of the Northwestern Province, February 19, 1919, PRAAD-Accra ADM56.1.278.

70. Letter from H.M. Berkeley, Commissioner of the Northwestern Province, to the Acting Commissioner of the Northeastern Province, April 30, 1919, PRAAD-Accra ADM56.1.278.

71. Letter from S.D. Nash, Commissioner of the Northeastern Province, to the Acting District Commissioner of Navarro-Zuaragu, June 4, 1919, PRAAD-Accra ADM56.1.278. For more on Nash and Cardinall as unusually perceptive administrators, see Allman and Parker, Tongnaab, chapters 1 and 2 .

72. In his reply, he pointed out the hypocrisy of restricting these migrants at a time when the government was promoting and enforcing long-distance labor, "I would further ask you, if the natives in question had migrated to Gambaga, Tamale, or Coomassie, would you have asked for their return?" Letter from S.D. Nash, Commissioner of the Northeastern Province, to the Commissioner of the Northwestern Province, June 28, 1919, PRAAD-Accra ADM56.1.278.

73. Letter from H.M. Berkeley, Commissioner of the Northwestern Province, to H.W. Leigh, Acting Chief Commissioner of the Northern Territories, Oct 27, 1919, PRAAD-Accra ADM56.1.278.

74. Leigh, presumably concerned with sparking conflict among his few DCs, left the issue unresolved-instructing in vague terms that "a personal investigation by the District Commissioner affected" should determine government action, without specifying how to resolve an issue on which two "affected" DCs disagreed so fundamentally. Letter from H.W. Leigh, Acting Chief Commissioner of the Northern Territories, to the Commissioner of the Northwestern Province, November 5, 1919, PRAAD-Accra ADM56.1.278.

75. Continued correspondence in 1920 and 1921 between Nash and Duncan-Johnstone, the DC of Lawra-Tumu, can be found in PRAAD-Accra, ADM56.1.278. When Michael Dasent returned three and a half years after his initial interaction with the Santejan case to find that the terms of debate had escalated, he argued that Cardinall's "fulsome journalese" was merely a cover for biased rulings and administrative inadequacy, pointing out that "under the administration of (Mr. A.W. CARDINALL) little or no Labour for outside has been recruited." Letter from Michael Dasent, DC of Lawra-Tumu, to the Commissioner of the Northern Province, June 17, 1922, PRAAD-Accra ADM56.1.278.

76. Letter from Louis Castellain, Commissioner of the Northern Province, to the DC of North Mamprusi, Navrongo, Nov 1, 1924, PRAAD-Accra ADM56.1.278.

77. Letter from the DC of North Mamprusi, Zuaragu, to the Commissioner of the Northern Province, July 21, 1925, PRAAD-Accra ADM56.1.278.

78. Letter from Louis Castellain, Acting Chief Commissioner of the Northern Territories, to the Commissioner of the Northern Province, August 6, 1925, PRAAD-Accra ADM56.1.278.

79. Letter from the Acting Commissioner of the Northern Province to the Chief Commissioner of the Northern Territories, February 5, 1924, PRAAD-Accra ADM56.1.278. Due to historical and agro-ecological factors, population densities are higher in the far North (what are now the Upper East and Upper West regions) than in what is now the Northern Region.

80. The suggested compensation, a relative fortune to a northern farmer, appears to have never materialized.

81. Charles Lynn, the first agricultural officer posted to the far north, came to the Zuarungu District in 1932, where he began directing locust control campaigns and then agricultural surveys and plans for "mixed farming" in the area. His survey work, published as the 
agricultural bulletin from the Department of Agriculture, Agriculture in North Mamprusi, Bulletin 34 (Gold Coast, 1937), became a key text in future plans for small-scale agriculture in the region. See Grischow, Shaping Tradition, chapter 5, 109-36. For more on Lynn, including the text of many of the letters he sent to his family while in northern Ghana, see Charles Lynn, Marjorie Lynn, and Silvia Lynn, The Long Garden Master in the Gold Coast: The Life and Times of a Colonial Agricultural Officer in the Gold Coast, 1929-1947 (Bedfordshire, 2012).

82. Acting Chief Commissioner Cutfield wrote in August 1928, "a great number of [people from Navrongo district] had moved from Wiasi area to South Mamprusi and from Talansi to South Mamprusi." Letter from Cutfield, Acting Chief Commissioner of the Northern Territories, to the Commissioner of the Northern Province, August 20, 1928, PRAAD-Accra ADM56.1.278.

83. Letter from P.F. Whittall, Commissioner of the Northern Province, to Cutfield, Acting Chief Commissioner of the Northern Territories, October 15, 1928, PRAAD-Accra ADM56.1.278.

84. Grischow, Shaping Tradition, chapters 6 and 8.

85. Letter from A.W. Cardinall, Acting Commissioner of the Northern Province, to the Chief Commissioner of the Northern Territories, March 14, 1928, Abangabisi Emigration, PRAAD-Tamale NRG8.2.23 (EAP 542/1/2/18).

86. The first reference to the Abangabisi disputants is February 1919, Navrongo-Zuarungu Informal Diary, PRAAD-Tamale NRG8.4.3 (EAP541/1/4/3).

87. The figure of seventy-five compounds is from a letter from the DC of South Mamprusi to the Acting Commissioner of Northern Province, March 13, 1929, and the estimate that each compound contained twenty people is from a letter from H.W. Leigh, Chief Commissioner of the Northern Territories, to the Colonial Secretary, June 28, 1929, PRAAD-Accra ADM56.1.278.

88. Letter from A.W. Cardinall, Acting Commissioner of the Northern Province, to the DC of South Mamprusi, March 20, 1929, and letter from G.F. Mackay, DC South Mamprusi, to the Acting Commissioner of the Northern Province, May 8, 1929, PRAAD-Accra ADM56.1.278. In demonstration of his support of the plan, the Mamprusi King (the Nayiri) began to offer migrants land near his residence in Nalerigu until they could settle on government-chosen sites.

89. In October, the DC of South Mamprusi remarked that "the system in regard to the NA having odd villages all over the country that follow him direct and cannot, if trouble arises or labour is required be sent to the Chief, in whose country they are, seems bad and uneconomical." October 1928, Excerpt from South Mamprusi Diary, Diaries, PRAAD-Tamale (EAP541.1.4.30 pt 1).

90. Memos between the DC of Zuarungu and the Commissioner of the Northern Province, August 28 and 29, 1929, PRAAD-Accra ADM56.1.278.

91. Letter from the DC of South Mamprusi to the Commissioner of the Northern Province, January 25, 1930, PRAAD-Accra ADM56.1.278.

92. Letter from G.F. Mackay, DC of South Mamprusi, to the Commissioner of the Northern Province, March 21, 1930, PRAAD-Accra ADM56.1.278.

93. Confidential Letter from the Acting Chief Commissioner of the Northern Territories to the DC Mamprusi Gambaga, November 10, 1932, Labour-Northern Territories, PRAADTamale NRG3.22.1.

94. Letter from F.W.F. Jackson, Chief Commissioner of the Northern Territories, to the Acting Commissioner of Northern Province, July 26, 1930, Labour-Northern Territories, PRAAD-Tamale NRG3.22.1.

95. ILO, Convention CO29, "Forced Labour Convention," June 28, 1930. http://www.ilo. org/dyn/normlex/en/f?p=1000:12100:0::NO::P12100_ILO_CODE:C029.

96. Article 10 of the ILO Forced Labour Convention, as quoted in Memo no. 634/30/5/50, "Maintenance of Roads Under the Forced Labour Convention," from Acting Colonial Secretary G.C. du Boulay, July 20, 1933, Labour-Northern Territories, PRAAD-Tamale NRG3.22.1.

97. Syme later clarified that, when he denied the use of forced labor in Bawku, this was because he excepted from his definition the practice by which in the "dry season the chiefs call out a certain amount of unpaid labour to work for a short period on the roads, and a few necessary repairs" on rest houses. He wrote that this would not qualify as forced labor but also could not be reported: "No record is kept of the numbers so employed or of the time 
spent on the work." "Owing to the large available population," he nevertheless reasoned, "the services performed must fall very lightly on the inhabitants." Telegrams and memos from J.K. Syme, Assistant DC Bawku, October and November 1932, Labour-Northern Territories, PRAAD-Tamale NRG3.22.1. The quotation is from a letter from Syme to the DC of Gambaga, November 15, 1932.

98. Roads that didn't qualify as either class A or C, and would have to be maintained by regional funds, were to be looked at extremely critically to see if they were "really necessary." Memo no. 634/30/5/50, "Maintenance of Roads Under the Forced Labour Convention," from Acting Colonial Secretary G.C. du Boulay, July 20, 1933, Labour-Northern Territories, PRAAD-Tamale NRG3.22.1. In his study of road labor in the Eastern Province of southern Ghana, Akurang-Parry argues that the category of "Class C" roads "was a strategy adopted by the colonial state to compel agricultural communities to build and maintain roads for transporting and marketing export cash crops as well as local staple crops." Akurang-Parry, "Colonial Forced Labor Policies," 20.

99. Staniland, The Lions of Dagbon, 83-84. To Jones and other proponents of indirect rule, one of the primary benefits of a native authority system would be to introduce a system of direct taxation administered by chiefs, a measure that Jones argued would relieve financial pressures and fund paid road gangs.

100. Letter from W.J.A. Jones, Chief Commissioner of the Northern Territories, to the Acting Colonial Secretary, Accra, January 21, 1935, Labour-Northern Territories, PRAADTamale NRG3.22.1. This letter was also forwarded to all northern DCs.

101. Ibid.

102. Letter from W.J.A Jones, Chief Commissioner of the Northern Territories, to the Colonial Secretary, Accra, June 5, 1935, Labour-Northern Territories, PRAAD-Tamale NRG3.22.1. This letter was also forwarded to all northern DCs. The sum was far beyond any allocation the central government was likely to grant. For comparison, the entire annual public works allocation in the 1946 ten-year development plan, which dedicated more resources to the North than had ever been contemplated, was £12,700. Paul André Ladouceur, Chiefs and Politicians: The Politics of Regionalism in Northern Ghana, (London, 1979), 70. Coming at the height of depression-era fiscal stringency, Jones's proposal was likely to garner nothing but laughter from the central government.

103. Letter from the Assistant DC of Navrongo-Zuarungu to the Chief Commissioner of the Northern Territories, September 6, 1933, Labour-Northern Territories, PRAAD-Tamale NRG3.22.1.

104. Letter from W.J.A Jones, Chief Commissioner of the Northern Territories, to the Colonial Secretary, Accra, June 5, 1935, Labour-Northern Territories, PRAAD-Tamale NRG3.22.1.

105. Letter from the Colonial Secretary to the Chief Commissioner of the Northern Territories, May 18, 1936, Labour-Northern Territories, PRAAD-Tamale NRG3.22.1.

106. Alice Wiemers, "When the Chief Takes an Interest': Development and the Reinvention of 'Communal' Labor in Northern Ghana, 1935-1960," The Journal of African History 58 (2017): 239-257. 